\title{
Antebellum Palingenetic Ultranationalism: The Case for including the United States in Comparative Fascist Studies
}

\author{
Stefan Roel Reyes \\ Southwest Texas Junior College \\ sreyes3937@gmail.com
}

\begin{abstract}
This article examines how the Southern proslavery defense produced a distinctly proto-fascist ideology. Rather than comparing the Antebellum South to twentieth century racist regimes, this study compares Southern fascist thought to Germany's nineteenth century Völkisch movement. The author uses Roger Griffin's Palingenetic Ultranationalism to explore how the Antebellum South promoted an illiberal vision of modernity. The author argues that proto-fascists rejected liberalism, had a profound sense of social decay, and advanced a vision of a new man, new political structure, and a new temporality. The striking similarities between nineteenth and twentieth century fascist movements mandates that the Antebellum American South should be included in comparative fascist studies. The results of this study contextualize the comparisons made between American racism and fascism along with deepening our understanding of fascism's protean qualities.
\end{abstract}

\section{Keywords}

United States of America - proto-fascism - palingenetic ultranationalism Antebellum - Völkisch - slavery

The European revolt against Positivism was a response to the social and cultural disruptions modernity entailed. This advance of liberalism and capitalism, which constitute modernity, produced massive discontent throughout Europe, sparking numerous movements and critiques of Europe's fin-desiècle culture. Various intellectuals produced illiberal and anti-Enlightenment

(C) ROEL REYES STEFAN, 2019 | DOI:10.1163/22116257-00802005

This is an open access article distributed under the terms of the prevailing CC-BY-NC license at the time of publication. 
ideologies during this era which laid the seeds for fascism's emergence in the next century. Fascist scholars routinely analyze this period in a comparative framework to understand the roots and features of these regimes. Nevertheless, often left out of comparative analyses is the United States. The United States' South, during the Antebellum period, produced its own unique form of illiberal discourse in promoting palingenesis - a revolutionary national rebirth. Southerners sought to reconfigure modernity according to their standards. They intended to establish a nation purged of liberal elements such as human rights, individualism, and democracy. Southern intellectuals advocated a renewed nation on the basis of elitism, inequality, and a third way between economic orders - an illiberal modernity best described as an industrialized slave state. The Southern Antebellum intellectual tradition warrants inclusion into fascist studies for its forward looking rejection of liberal modernity.

Numerous scholars have drawn parallels between the anti-democratic thought in the American South and the fascist movements of the twentieth century. In fact, such comparisons have also been made by Nazis and their victims. ${ }^{1}$ Nonetheless, this scholarship has not been without its own shortcomings. There is a gap in how Southern thought compares to Europe's fascist forerunners. Part of the problem is that the Southern proslavery arguments, nationalism, and secessionism have been traditionally viewed in isolation and not as part of the larger European revolt against Positivism. Indeed, Joseph Yaneilli recognized this and advocated examining fascism as part of a larger international context. He joins an expanding literature which views American slavery and European fascism as intertwined through time and space. ${ }^{2}$ Nonetheless, even with the comparisons made between fascist Germany and the United States there is a disproportionate emphasis on the Nazis and twentieth

1 The United States had long been an important contributor to racialized science before the Civil War. For example, American racist scientist Samuel G. Morton commanded respect for his racial knowledge from the esteemed European scientist Louis Agassiz. See Bruce Dain, $A$ Hideous Monster of the Mind: American Race Theory in the Early Republic (Cambridge: Harvard University Press, 2003); see Timothy Snyder, Black Earth: The Holocaust as History and Warning (New York: Tim Duggin Books, 2015), 12-20 for an excellent exegis of how Hitler was inspired by the trajectory of American history. In this book, Timothy Snyder quotes a Ukrainian woman's diary entry: 'We are like slaves. Often the book Uncle Tom's Cabin [author's italics] comes to mind. Once we shed tears over those Negroes, now obviously we ourselves are experiencing the same thing'(page 18).

2 see also Nancy K MacLean, Behind the Mask of Chivalry: The Making of the Second Ku Klux Klan (New York: Oxford University Press, 1995); and Richard Steigmann-Gall, 'Star-spangled fascism: American interwar political extremism in comparative perspective, Social History 42, no. 1 (2017): 94-119. 
century America with virtually no representation of pre-Civil War America in the literature. Another issue with the South in relation to fascist studies is that scholars have simply labelled Southern thought as authoritarian or fascist without specifying any criteria or applying any model of fascism. For example, American historian Harvey Wish argued American Southern intellectual George Fitzhugh's anti-democratic attack on liberalism and capitalism constitute his proto-fascism. Likewise, Manisha Sinha analyzed that, in their defense of slavery, Southerners promoted a distinctly authoritarian and antienlightenment perspective. Even Robert T. Bonner, who linked the thread of racism between the Confederacy and Nazi Germany, did not analyze, in length, the more general proto-fascist ideological similarities between the two.

\section{Methods}

In this article, I address these gaps in the literature through a comparative analysis of proto-fascist intellectuals in the American South and in Europe. I do not believe that comparing Southern Antebellum thought to full-fledged twentieth century fascism is the ideal method of comparison. It is more appropriate to situate American proto-fascism with the pre-World War I fascist intellectuals of Europe who laid the foundation for fascist regimes to take root after the First World War. For this study, the Völkisch intellectuals of nineteenth century Germany are chosen as a unit of comparison. The ideologies of the Southern and Völkisch intellectuals are apt models of study for several reasons; the intellectuals of each society displayed a contempt for liberalism and a praise for aristocratic and elite rule. They both believed in subordinating the wishes of the individual for the greater good of the social order. They sought a palingenesis to protect against the degenerative influence of modernity. In doing so, the intellectuals in these countries contributed to regimes founded upon racism and defeated in war. Furthermore, Southern and Völkisch intellectuals produced ideologies which contributed to fascist regimes. Through scaling back the historical analysis to the epoch before the First World War, we can understand how modernity evoked very similar processes in which a devastating war would take the American South and Europe in divergent directions. Therefore, Southern and Völkisch intellectuals offer an excellent protofascist comparison that harbored palingenesis at its core.

Analyzing the similarities in the American South and in Germany's Völkisch movement illuminates the Southern intellectual tradition rightfully as part of the general European revolt against Positivism. The ideological discourse of the Antebellum South can best be described as proto-fascist. Although 
Southern intellectuals developed a strong palingenetic nationalism, they were ultimately hindered by the elitism and lack of widespread propaganda and mass political participation that engaged European populations in the next century. Nonetheless, the palingenetic ultranationalism of the South has enough similarities to be seriously considered an ideological counterpart to Europe's fascist regimes. Proto-fascism is a heuristic emphasizing a shared notion of rebirth (palingenesis) to, but lacking many features of, interwar or 'fullfledged' fascism. To put another way, proto-fascism was the nineteenth century revolt against the existing liberal modernity and search for alternative modernity that preceded Nazi Germany and Fascist Italy.

In the search for a 'fascist minimum' scholars have developed a set of diverse and overlapping criteria, much of which is applicable to the Southern pro-slavery ideology. For example, if we use Robert Paxton's Five Stages of Fascism, the intellectual tradition of the South shares fascists' sense of the primacy of the group, a sense of victimization and decadence, an enhanced sense of identity and the authority of natural leaders. If we apply Stanley Payne's criteria, both Southern and European fascist schools of thought nurtured and promoted anti-liberal and anti-communist agendas, exalted the idea of an authoritarian state, pursued aggressive territorial expansion, and held a positive conception of violence. If we bring in the framework for Jason Stanley's analysis of fascist politics, the South not only fits within his 'Us vs Them' argument but also matches other criteria including the hierarchy of nature, victimhood, and a fear that sexuality as well as law and order would be undermined. However, for this study, I use Roger Griffin's model of palingenetic ultranationalism; defined as a political form of modernism seeking a new nation through rejecting liberal aspects of modernity. ${ }^{3}$ The attempted result is a new society which is illiberal in a particularly Southern way. This same ineliminable core of palingenesis which Griffin used to explore 'post-fascist' movements can also be applied retroactively to investigate proto-fascism. ${ }^{4}$ Griffin's model is fluid, yet coherent, and takes into account the unique national and cultural characteristics that contribute to the differences in fascist movements. The susceptibility

3 Roger Griffin, Modernism and Fascism: The Sense of a Beginning under Mussolini and Hitler (Basingstoke: Palgrave Macmillan, 2007), 348-349; and Roger Griffin, 'Modernity Under the New Order: The Fascist Project for Managing the Future,' in A Fascist Century: Essays by Roger Griffin, ed. Matthew Feldman (Basingstoke: Palgrave Macmillan, 2008), 27-31.

4 Roger Griffin, 'Fascism's New Faces (and Facelessness) in the "Post-Fascist” Epoch,' in A Fascist Century: Essays by Roger Griffin, ed. Matthew Feldman (Basingstoke: Palgrave Macmillan, 2008), 181-202. 
of palingenetic ultranationalism to external forces explains each fascist movement's 'special path,' adjacent properties, or organizational structures.

This analysis of the palingenetic ultranationalism of the American South is an investigation into the intellectual history of Germany's Völkisch movement and the proslavery defense in the United States. The Southerners' defense of slavery created palingenetic ultranationalism. Some of these individuals were influential in fostering Southern nationalism on the national stage. For example, Senator John C. Calhoun's A Disquisition on Government gave legitimacy to the threat of the North and created the space to allow Southern Fire-Eaters to emerge. These Fire-Eaters were ardent ultranationalists who were the strongest supporters of secession and the formation of a new nation that eventually culminated in the Confederate States of America. Other members of the Southern intelligentsia were widely read and some defended slavery so ardently as to herald the era of fascism and totalitarianism of the next century. For instance, the self-educated intellectual George Fitzhugh consumed the works of Gobineau and Carlyle and was self-aware in the sense that he understood his European contemporaries to be dealing with similar issues of liberal decadence; his palingenetic nationalism is as much as a revolt against American liberalism as much as it is a reaction to the legacy of the French Revolution. However, Fitzhugh was not alone, his illiberal ideology was bolstered by the likes of Henry Hughes and James Henry Hammond, among others. Although many of these Southern intellectuals are regarded by most historians as fringe theorists, they cumulatively created the palingenesis of the Antebellum South. In the case of Fitzhugh and Hughes, they accurately predicted the course of Southern economic modernization. ${ }^{5}$ Their European contemporaries are the proto-fascist Völkisch intellectuals Paul de Lagarde and Wilhelm Heinrich Riehl.

I argue that the Antebellum South's palingenetic ultranationalism warrants its inclusion into the discourse of comparative fascist studies. Specifically, I advance the literature through analyzing the similarities between Southern and Völkisch intellectuals. I begin this study examining how the Southern defense of slavery birthed palingenetic ultranationalism. Defending human bondage necessitated an attack on liberal democracy. The abolitionist movement

5 Chad Morgan, 'Progressive Slaveholders: Planters, Intellectuals, and Georgia's Antebellum Economic Development,' The Georgia Historical Quarterly 86, no. 3 (2002): 398-422. 
created a pervasive sense of victimization and decadence that contributed to a longing for a palingenesis in the South. Then, I briefly examine the social, political, and temporal aspects of this envisioned national rebirth as an alternative to liberal modernity. Throughout this endeavor, I outline the shared palingenetic characteristics between the proto-fascist intellectuals of the American South and of Germany's Völkisch movement. This article is intended as a launching point for further investigative analyses over the shared proto-fascist features between the Antebellum South and Europe.

3

\section{Decadence: The Progenitors of Southern Palingenetic Ultranationalism}

Various proto-fascist movements circulated in fin-de-siècle Europe. These included organizations such as France's Action Française or Russia's Union of Russian People. Intellectuals played an influential role in shaping the pessimism toward contemporary culture that gave individuals the space to express their sentiments in these movements. For Germany, these were the Völkisch intelligentsia who criticized modernity's sweeping transformations. Rapid technological, social, and cultural transformations imbued many with a sense of chaos and social decay. Many intellectuals across the continent responded to this social transformation through harboring and nurturing antiEnlightenment concepts. Proto-fascist intellectuals paved the way for the rise of Fascism by weakening society's affirmation of Enlightenment-liberal values. ${ }^{6}$ In this way, these intellectual forerunners of fascism laid the foundation for fascist ideologies to emerge in the next century - though not always successfully - after the epoch changing Great War.

Frequently omitted from this discourse is the fact that many pro-slavery Americans of the South were playing similar roles to their European contemporaries. Defending slavery necessitated an attack against both capitalism and liberalism. In laying the ideological framework for an insurrection against the United States, Southern intellectuals promoted a distinctly proto-fascist ideology. That is, they fostered the drive toward palingenesis that culminated in the Confederate States of America. They were creating space, in the same manner as Völkisch thinkers, for later illiberal ideas to take hold. The Southern slavocracy believed they faced victimization, vassalage, and servitude under an increasingly threatening North. An atmosphere of cultural pessimism pervaded Southern elites. To many Southerners, the North represented the worst of

6 Robert Paxton, The Anatomy of Fascism (New York: Vintage Books, 2004), 18. 
modernity - liberal democracy and laissez-faire capitalism. It is important to clarify that the South was also capitalist. However, although I will use capitalism as a shorthand for the North, I use the term in a very specific sense. Northern capitalism was liberal in an Enlightened sense and therefore antithetical to Southern capitalism. Northern capitalism was defined by free labor and free soil - not slavery. The capitalism of the North derived from the economic Enlightenment of Adam Smith who envisioned laissez-faire capitalism as a liberating force to foster human freedom through prosperity and in rendering slavery obsolete. ${ }^{7}$ The capitalism the South defended was illiberal in its use of slavery and the legacy of the mercantilist and feudalist days of early capitalism. Nonetheless, Southerners believed that they needed to break away not simply to preserve their institution of slavery, but also to protect Southern society from the 'isms' of the North - largely abolitionism which many Southerns conflated with socialism, communism, feminism, and anarchism.

To many of the Southern intelligentsia, the emancipated black individual symbolized liberal modernity. Abolition not only represented the destruction of the racial order but the advent of capitalism. Many Southerners believed Northern industrial-capitalist development came at the expense of their region. Capitalism for the South was linked to the free soil movement and the newly forged Republican party. Southerners portrayed capitalism as synonymous with many social justice or socially progressive issues of the era. The massive economic inequalities during early industrialization meant that disgruntled workers were often not only at the forefront of socialism but also abolitionism, feminism, and greater democracy - or at least they were perceived as such by Southerners. Revealing the association of abolitionism with liberalism is the Southerner Edwin C. Holland, who denigrated slaves as Jacobins and anarchists. ${ }^{8}$ Furthermore, many Southerners recoiled in horror at the prospect of a category of individuals they deemed inferior having the opportunity to be treated on an equal basis. This notion was anathema to a society which had always been predicated upon human bondage. These fears contributed to a feeling of social decay in the South. To protect slavery was to attack capitalism and liberalism. The defense of slavery required an intellectual assault on ideals of equality, human rights, and democratic participation.

7 For capitalism as an Enlightenment ideology see Elizabeth Anderson, Private Government: How Employers Rule Our Lives (and Why We Don't Talk about It) (Princeton: Princeton University Press, 2017). For capitalism as way toward abolition see: David Brion Davis, The Problem of Slavery in the Age of Revolution, 1770-1823 (New York: Oxford University Press, 1999), 351.

8 Manisha Sinha, The Counter-Revolution of Slavery: Politics and Ideology in Antebellum South Carolina (Chapel Hill and London: The University of North Carolina Press, 2000), 15, 91. 
South Carolinian representative John C. Calhoun was the avant garde leading the attack against America's liberalism with his influential work, Disquisition on Government. Within this work, he promoted the notion of the concurrent majority. The concurrent majority was an attempt to promote the function of the American government to preserve the rights of minorities through limiting majority rule. In essence, it was a way for an elite cadre of slave owners to preserve chattel slavery in the face of growing public opinion desiring an end to the practice. So great was his desire to protect slavery that Calhoun produced one of his most infamous remarks in his work: These great and dangerous errors have their origin in the prevalent opinion that all men are born free and equal; - than which nothing can be more unfounded and false. ${ }^{9}$ Calhoun's thesis were much more a reflection of his own disdain for the increasingly democratic nature of the United States and the threat majority rule posed to the property rights inherent in slave ownership. Calhoun's ideas nurtured a generation of Southern nationalists who harbored fantasies of a new Southern nation. He was one of the leading defenders of slavery in the South during the Antebellum era and, consequently, his views had a massive impact on later pro-slavery ideologues. ${ }^{10}$ By defending the interests of a small elite, Calhoun opened the intellectual doors toward the broader criticism of the notion of equality and democracy.

Perhaps Calhoun's greatest illiberal predecessor was the Virginian born social theorist George Fitzhugh. Fitzhugh produced two great texts along with a flurry of articles criticizing liberalism through advocating slavery. The title of his first book Sociology for the South, or, the Failure of Free Society perfectly sums up his attack on American modernity. In defending slavery, Fitzhugh attacks the theories of John Locke, Thomas Jefferson, and Adam Smith. The entire objective of Sociology for the South was to prove liberal institutions and free societies are social experiments doomed for failure. In his eyes, it is the competition inherent in capitalism which fosters degeneracy: 'In free society the sentiments, principles; feelings and affections... [are] debased by the continual war of competition.... the rich have their temptations, too. Capital gives them the power to oppress; selfishness offers the inducement, and political economy, the moral guide of the day, would justify the oppression. ${ }^{11}$ Capitalist societies promote selfish virtues at the expense of everyone - destroying the previous systems of morality which fostered cooperation: 'free society. Its

John C. Calhoun, A Disquisition on Government and a Discourse of the Constitution and Government of the United States (Columbia, S.C.: A. S. Johnston, 1851), 57.

10 Sinha, The Counter-Revolution of Slavery, 87-88.

11 George Fitzhugh, Sociology for the South, or the Failure of Free Society (Richmond, V.A.: A. Morris, 1854), 38-39. 
crimes, its revolutions, its sufferings and its beggary, have led us ... to show that free society is a failure and its philosophy false.'12 The selfishness and competition of free society breeds social decay. This is a point reiterated, nearly verbatim, with his follow up sequel Cannibals All! However, it is this attack against the decadence produced by liberalism and capitalism that aligns him with his German Völkisch contemporaries.

The proto-fascists of the South and Germany held similar conceptions of modernity, particularly in capitalism's destruction of traditional culture. Völkisch intellectual Paul de Lagarde questioned the viability of liberal society as much as Fitzhugh. For the Southerners, liberal modernity not only represented miscegenation, emancipation, and the loss of wealth but chaos, anarchy, and an unfathomable socio-cultural revolution. As Fitzhugh launched: 'Western European Society, which has been engaged in continual revolution for twenty years, has satisfied us that Free Society everywhere begets isms, and that isms soon beget bloody revolutions. ${ }^{13}$ Völkisch intellectuals, along with their fascist successors, reacted to liberalism in a comparable manner. Wilhelm Heinrich Riehl in his Land und Leute [Land and People] cited the social tumult in the wake of the 1848 revolutions as evidence of the decay inherent in liberal societies: 'The Germanic idea of community ownership, of the market cooperatives, of the joint guarantee of the communities, and, apparently, a precursor to the general community of property, has never awakened modernday communism. ${ }^{14}$ That is, the arrival of modernity disrupted Germany's communities and culture. For Riehl and Lagarde, modernity destroyed traditional culture and values and replaced them with abstract ideologies discordant to the needs of the people. In this process, the unique cultural and social peculiarities of regional Germans were erased and replaced with modern ideas such as equality and democracy. For Fitzhugh, capitalism and free trade promoted a similar cultural hegemony, a cosmopolitan culture that devalued local affinities, destroying patriotism and erasing distinctions of nationality..$^{15}$

To the anti-Enlightenment intelligentsia in both continents, however, such notions were not merely abstract; aside from the visible changes of industrialization, both societies used scapegoats to symbolize degeneration. Southerners believed slaves were an inferior subspecies that needed to be kept down in order to preserve the tranquility of the South. Furthermore, black and female

\footnotetext{
12 Fitzhugh, Sociology for the South, III.

13 George Fitzhugh, Cannibals All! Or, Slaves Without Masters (Port Royal, Caroline V.A.: A. Morris, 1857), xviii.

14 Wilhelm Heinrich Riehl, Land und Leute (Stuttgart and Tubingen: J.G. Cotta, 1854), 97.

15 Michael O'Brien, Conjectures of Order: Intellectual Life and the American South 1810-1860 (Chapel Hill and London: The University of North Carolina Press, 2004), 983.
} 
abolitionists in the North represented a cultural revolution in the relationship between race and sex. The advocation for the expansion of rights in the United States threatened the culture of conservatism in the Antebellum South. Similar to intolerance of their American counterparts, anti-Semitism gained ground in Germany at the end of the nineteenth century. Lagarde, in particular, believed that Jews and liberals were co-conspirators in sweeping away German culture, modernizing society, and contributing to social decay. ${ }^{16}$ Being so threatened by the forces of modernity, the Southern and Völkisch protofascists believed a new nation needed to be founded to combat these hostile encroachments.

Liberal progress evoked a deep sense of social degeneration in Antebellum and German societies. The proto-fascist intellectuals of each nation developed and refined the idea of palingenesis as an alternative to the sweeping changes in society. Lagarde advocated the establishment of a new Germanic faith as a means of destroying liberalism, uniting the Volk, and salvaging the nation. ${ }^{17}$ Like their European contemporaries, the Southern pro-slavery defenders envisioned a new Southern modernity as a means to establish a bulwark against the North's degenerate liberal modernity. It was an attempt to preserve their mythological perspective of Southern perfection. Southern and Völkisch intellectuals also arrived at similar perspectives about how this new nation would look. It was to be ruled by an aristocratic elite.

4

Toward a Social Palingenesis: The Exaltation of Elitism, Patriarchy, and the New Man

Now that we have outlined the sense of degeneracy which Southerners and Völkisch intellectuals shared, we next need to examine the similarities in their palingenetic vision of the future. In crafting a defense of slavery, Southern intellectuals envisioned a new society, rooted in the traditions of their culture, where a new man would take his rightful place amongst women and slaves. The South promoted a distinctly American form of elite driven patriarchy to constitute this new Southern order. It is important to note, the Antebellum South was already defined by an elite patriarchy, however, Southerners believed it to be under threat from abolitionism and feminism emerging during

16 Fritz Stern, The Politics of Cultural Despair: A Study in the Rise of Germanic Ideology (Berkeley: University of California Press, 1989), 64.

17 Paul de Lagarde, Deutsche Schriften [German Writings] (Göttingen: Dieterich'sche Verlagsbuchhandlung, 1878), 64 . 
the era. In his chapter 'The Family,' Fitzhugh regards abolition as the mere beginning of the breakdown of all order: 'First domestic slavery, next religious institutions, then separate property, then political government, and, finally, family government and family relations, are to be swept away.'18 In advocating for the re-birth of a new nation, through secession, the Southern intelligentsia wanted to carry over this patriarchal heritage as one of the foundational pieces of their new nation. The patriarch was not merely a member of a master race and master sex, but also, a master class destined to create this new society.

Southern intellectuals supported the patriarchal institution of Paternalism as the paragon of aristocratic governance. This was a conception of order in which the authoritarian power of the patriarch allowed him to rule over his wife, children, and slaves. ${ }^{19}$ Women, children, and blacks had the right to protection, at the cost of obedience. The Southerner believed the patriarch to be an agent of stability and civilization, morally and culturally uplifting his family of wife, children, and slaves. This elite driven patriarchy, mythologized as a benevolent institution, was critical to the social order and stability of the Southern way of life. As abolitionism increased in the United States, the Southern intelligentsia increasingly perceived Paternalism as a critical bulwark preventing the 'isms' of the North and thereby social decay and chaos.

However, although Paternalism reflected the desire to resist liberalism, it was also an ideology believed to reflect the qualities of the natural world. Particularly, the inequality between men, women, and race. Southern intellectuals believed that liberalism, democracy, and equality were false ideologies because their way of life was built on inequality; the primacy of the patriarch and the subordination of all others. They believed that the social order should be constituted to reflect the inequalities inherent in nature. Calhoun paved the way in stating that liberty: 'is a reward to be earned ... reserved for the intelligent, the patriotic, the virtuous, and deserving. ${ }^{20}$ Not even the esteemed Senator and Governor of South Carolina, James Henry Hammond believed all white men were equal amongst each other. ${ }^{21}$ Fitzhugh expanded upon the South's belief in inequality, stating: 'The order and subordination observable in the physical, animal and human world, show that some are formed for higher, others for lower stations - the few to command, the many to obey. . . Not to make them rulers or masters, is as great a violation of natural right, as not

18 Fitzhugh, Cannibals All!', 281.

19 O'Brien, Conjectures of Order, 977.

20 Calhoun, A Disquisition on Government, 55 .

21 Sinha, The Counter-Revolution of Slavery, go; see also Ned Sublette and Constance Sublette, The American Slave Coast (Chicago: Lawrence Hill Books, 2016), 604. 
to make slaves of the mass.'22 Fitzhugh saw inequality as an essential component of Paternalism and social welfare in society: 'Slavery secures intelligent rulers, interested in the well-being of its subjects ... This social organization begets harmony and good will.23 Although paternalism was a self-justification for slavery, its usefulness as an ideology transcended harmony and stability for it was a critical component in the elevation of society as a whole.

Southern intellectuals also portrayed the patriarch as an agent of civilization and stability. Slavery was seen as essential in containing and uplifting African Americans above their perceived status as animals. Fitzhugh argued that: 'Slavery educates, refines and moralizes the masses by separating them from each other, and bringing them into continual intercourse with masters of superior minds, information, and morality. ${ }^{24}$ However, similar connotations were applied beyond the plantation. Southerners even portrayed aristocratic slave ownership as a means of cultivating civilization, not only among slaves, but also white yeomen. Senator William Harper believed the Southern patriarchy would: 'obtain all the good which has resulted from monarchies and aristocracies.' ${ }^{25}$ Such an idea of aristocracy was taken with pride in Daniel R. Hundley's 'Social Relations in Our Southern States.' He takes satisfaction in the genealogy of Southern gentlemen, noting he 'comes usually of aristocratic parentage' and it is the Southern gentlemen's flawless pedigree which is partly the foundation for his elevated decorum, conduct and being - the other part being his role as a slave master: 'The natural dignity of manner peculiar to the Southern Gentlemen, is doubtless owing to his habitual use of authority'. ${ }^{26}$ In their palingenetic vision, a Southern confederacy would not only keep pure the Southern way of life against what was increasingly believed to be a degenerate North but serve as a creative and civilizing function in society. In some cases, Southerners reached back into the Medieval Ages as a model of the elites' creative function. For example, Hammond declared: "The British government with its monarch and a "rich, hereditary, permanent aristocracy" [are] . . . the most "perfect" system of governance. ${ }^{27}$ In these conceptions, the patriarch was an agent of

\footnotetext{
22 Fitzhugh, Cannibals All!, 102-103.

23 George Fitzhugh, 'Southern Thought Again,' De Bow's Review: Agricultural, Commercial, Industrial Progress and Resources 23, issue 5 (1857): 449-462. Available at Making of America, accessed November 27, 2019, http://quod.lib.umich.edu/m/moajrnl/acg1336.123.005/453. 453-45.

24 Fitzhugh, 'Southern Thought Again,' 454.

25 Sinha, The Counter-Revolution of Slavery, 34.

26 Daniel R. Hundley, 'The Southern Gentleman,' in The Causes of the Civil War, ed. Kenneth Stamp, 3rd revised edition (New York: Simon \& Schuster, 1991), 206-208.

27 Sinha, The Counter-Revolution of Slavery, 123.
} 
civilization and order precisely because he wielded despotic power over his feudalistic plantations.

The ideas of a new aristocratic society were not solely limited to the South, similar ideas were expressed in the Völkisch movement as well. A common theme interwoven in Völkisch works is the exaltation of nature and the belief that one and the community should conform to the natural world. Völkisch intellectuals viewed the medieval aristocracy as a reflection of the inequality inherent in the natural world. Like their Southern contemporaries, the Völkisch intelligentsia assumed that nature creates differences among men and therefore, the inequality between races and people reflects the axiomatic designs of nature. To have unequal societies is to have societies in concordance with nature. Another reason for the extreme reaction against liberalism was that, in many cases, proto-fascists equated God with the natural order. God created inequality, rank, and hierarchy in the natural world and in human societies. According to Lagarde, every individual has a unique position in the social hierarchy assigned to him - something ideas of equality and liberty violated. ${ }^{28} \mathrm{La}-$ garde believed in the divine right of Germany's medieval nobility. He believed that the true nature of the Volk was aristocratic because the people corresponded to nature. Lagarde believed this God ordained order inspired harmony and prevented radical change. His central thesis in Deutsche Schriften was that this ancient nobility needed to be re-instituted as part of a new Germanic faith that would sweep away modernity's deleterious influences. ${ }^{29}$ Similarly, Riehl also believed that hierarchies are natural and it is modernity which is alien for the aristocracy preserved the true nature of the Volk. ${ }^{30}$ Such ideas were not limited to Europe. For the South, hierarchy, inequality, and slavery was, too, a patriarchal system descended from God. ${ }^{31}$ With such strong convictions, it is no wonder the South sought a palingenesis. They regarded their aristocracy not only as the best hope for the future of humanity but as a God ordained institution besieged ${ }^{32}$ For the Southern intelligentsia, to allow Northern abolitionists to criticize slavery was intolerable.

Nonetheless, perhaps the largest hindrance toward the development of a populist fascist movement was the proto-fascist cult of aristocracy. The protofascist image of the new man is rooted in traditional elitist conservatism and excluded popular participation. Nevertheless, there were signs that this

\footnotetext{
28 Stern, The Politics of Cultural Despair, 59.

29 Lagarde, Deutsche Schriften, 253.

$30 \quad$ Riehl, Land und Leute, 29.

31 O'Brien, Conjectures of Order, 959-960.

32 Sinha, The Counter-Revolution of Slavery, 141.
} 
position was untenable. Southern elites were facing increased pressure from a newly emerging class consciousness of the poor and sought ways to mobilize popular participation to the extent possible at the time. ${ }^{33}$ The South's emphasis on the white race was, to a certain degree, a populist message which promised to elevate the non-slave owner through his skin color. Fitzhugh even advanced the idea of a Southern education to disseminate principles of the new man: 'We alone are a new people. Our social relations and institutions differ widely from those of other civilized countries of modern times, and in some respects from those of antiquity. New, original, and valuable combinations of thought will be suggested by our social organism ... A Southern university will beget Southern thought and a Southern literature ... When we cease to study Northern and European books ... [we will] build up a Southern literature, more truthful, more Christian, more natural, and therefore superior to any that has preceded it.' ${ }^{34}$ In fact, Fitzhugh advocated the elevation of white masses to the positions of superiority: 'Our citizens, like those of Rome and Athens, are a privileged class. We should train and educate them to deserve the privileges and to perform the duties which society confers on them.'35 Later, in Sociology for the South, Fitzhugh continues to venerate classical aristocracies as a paragon, 'Like the Roman citizen, the Southern white man would become a noble and a privileged character. ${ }^{\prime 6}$ De Bow contributor, L.W. Spratt believed that reopening the Atlantic slave trade would open Southern slavery to the masses, enabling popular participation in the slavocracy. In De Bow's Review, he stated: 'for all to become slave owners ... will thus bring all the ruling race to the same social stand point; it will thus reintegrate and erect our social system ... and open the prospect to a broader and brighter future than was ever yet expanded to the eye of man.'37 Although the South was a rigid oligarchy, Southern intellectuals envisioned popular participation in the creation of the new man;

33 For Southern class consciousness, see: Keri Leigh Merritt, Masterless Men: Poor Whites and Slavery in the Antebellum South (Cambridge: Cambridge University Press, 2017).

34 George Fitzhugh, 'German Literature,' De Bow's Review: Agricultural, Commercial, Industrial Progress andRresources 29, issue 3 (1860): 289-290. Available at Making of America, accessed November 27, 2019, http://quod.lib.umich.edu/m/moajrnl/acg1336.1$29.003 / 284$.

Fitzhugh, Sociology for the South, 93 .

36 Ibid., 147-148.

37 L.W. Spratt, 'Report on the Slave Trade, to the Southern Convention,' De Bow's Review: Agricultural, Commercial, Industrial Progress and Resources 24, issue 6 (1858): 488. Available at Making of America, accessed November 27, 2019, http://quod.lib.umich.edu/m/ moajrnl/acg1336.1-24.0o6/492. 
heralding the future arrival of the populist ultranationalism of future fascist regimes.

\section{Toward a Political Revolution: Freedom Through Society, Not Through Individualism}

Promoting the role of elites whilst attacking notions of equality and democracy tended toward justifying not only inequality but also authoritarianism. In this sense, I use the term authoritarian to mean illiberal. That is, authoritarianism was a component of many fascist regimes. Specifically, it was the idea that the nation grants an individual's rights which was a common thread linking Southern and fascist ideologies. For example, in one Nazi boarding school, the regime quoted Paul de Lagarde directly: "That man is not free who can do as he likes, but he is free who does what he should do. ${ }^{38}$ Similarly, in the Southerner's dreams of palingenesis, the individual's rights would be co-opted for the greater good of Southern society. Calhoun and Fitzhugh's attacks on American liberalism make clear that the individual possesses no natural rights outside of society, it is society which determines the individual's rights. In this conception, individuals were but mere building blocks toward the stability and order that the Southern intellectuals envisioned.

Southern ideology heralded the fascism of the next century. Calhoun legitimized the authoritarianism of the slavocracy through directing his criticism against the founding liberal ideals of the United States. In attacking the State of Nature that birthed American notions of equality, Calhoun stated: 'there never was such a state as the, so called, state of nature, and never can be, it follows, that men, instead of being born in it, are born in the social and political state; and of course, instead of being born free and equal, are born subject, not only to parental authority, but to the laws and institutions of the country where born, and under whose protection they draw their first breath', he continued, 'the more perfectly a government combines power and liberty, — that is, the greater its power and the more enlarged and secure the liberty of individuals. ${ }^{39}$ In his Treatise of Sociology, Theoretical and Practical, Henry Hughes anticipates the coming fascist century. Hughes makes it clear that a society's priority is its continual existence, individual well-being and freedom are

\footnotetext{
38 George L. Mosse, The Fascist Revolution: Toward a General Theory of Fascism (New York: Howard Fertig, 1999), 128.

39 Calhoun, $A$ Disquisition on Government, $5^{8-59 .}$
} 
merely ancillary toward this end. ${ }^{40}$ The individual has no natural rights, only those which the state decides to give to its citizens. Hughes believed that the governing mechanism of society is not the free association of sovereign individuals, but rather, the brute force of power: 'Desire and fear are the springs of human action. By ordering these, men are ordered. ${ }^{41}$ The Southern intelligentsia made clear that society does not exist for individuals - individuals are created by and for society.

The contempt for the liberal tradition reaches its zenith in the works of Fitzhugh. He proclaimed: 'All human experience proves that society must be ruled not by mere abstractions [like liberalism or natural rights], but by men of flesh and blood. To attain large industrial results, it must be vigorously and severely ruled. ${ }^{42} \mathrm{He}$ reiterates the same point in his follow up work saying: 'We do not agree with the authors of the Declaration of Independence, that governments "derive their just powers from the consent of the governed.". . All governments must originate in force and be continued by force. ${ }^{43}$ Fitzhugh promotes social cohesion and indoctrination in contrast to freedom of conscience and individual liberty: 'An isolated man is almost as helpless and ridiculous as a bee setting up for himself. Man is born a member of society, and does not form society.' In the next sentence he bolsters the Southern ideology of illiberalism and the diminutization of individual rights:

Nature, as in the cases of bees and ants, has it ready formed for him. He and society are congenital ... He has no rights whatever, as opposed to the interests of society; and that society may very properly make any use of him that will redound to the public good. Whatever rights he has are subordinate to the good of the whole; and he has never ceded rights to it, for he was born its slave, and had no rights to cede. ${ }^{44}$

It is important to clarify, that Fitzhugh's defense of slavery involves reducing all relationships to the binary of slaves and masters. This, naturally, is his major lynchpin in his defense of slavery.

Proto-fascists between the South and Germany believed stripping the individual of their rights created a better society. Although the assault on individual liberty strikes at the very foundations of American notions of freedom,

40 Henry Hughes, Treatise of Sociology: Theoretical and Practical (Philadelphia: Lippincott, Grambo \& Co., 1862), 47.

41 Hughes, Treatise of Sociology, 55 .

42 Fitzhugh, Sociology for the South, 70.

43 Fitzhugh, Cannibals All!', 353.

44 Fitzhugh, Sociology of the South, $25^{-26}$. 
Southern intellectuals portrayed their alternative in a positive manner. George Fitzhugh likened the authoritarian nature of his palingenetic vision to a type of fraternity. He stated: 'society does not owe its sovereign power to the separate consent, volition or agreement of its members. Like the hive, it is as much the work of nature as the individuals who compose it... It makes each society a band of brothers, working for the common good'. In fact, he believes the supremacy of the state is what contributed to the greatness of antiquity, 'In ancient times, the individual was considered nothing, the State everything ... under this system, the noblest individuality was evolved that the world has ever seen. ${ }^{45}$ Fitzhugh's conception of slave society as a hive united in a similar mentality is comparable to the Völkisch nostalgia for the nobility of the Medieval Ages. For Völkisch intellectuals, freedom is found in the German aristocracy. Lagarde believed the German aristocracy, through deference and recognition of the natural inequalities, binds the community together, liberates the Volk from liberalism, and gives rise to the real German nation. ${ }^{46}$ In Völkisch ideology, the people only experience their freedom through the prince and nobility. Similarly for Riehl, a feudal society governed by an explicit hierarchy was an ideal system of unity and harmony. A society ran according to these Romantic presuppositions was a society that, together, united individuals into a project greater than their own being. The proto-fascists of the South and of Germany are ultimately linked through the attack on individualism in favor of a post-liberal collectivity which they believed liberated and elevated the individual.

In the face of growing change, the Southern illiberal ideology sought to reorientate the individual within an authoritarian - and as we will see in the next section - somewhat totalitarian state. In promoting the idea of a renewed nation, Southern intellectuals sought priority in the national community over the rights of the individual. The South sought to unify their people around white supremacy under the tutelage of a slavocracy. The critiques of Calhoun and the overall popularization of palingenesis reinforced the sense of Southern identity and nationalism. While lacking an emphasis on a single leader or explicit leadership principle, the South supported an elite aristocracy and Paternalism; though, there were clear indications that a new Southern nation would need to incorporate popular participation. These attacks on individual liberty are strands of thought which link American and Völkisch proto-fascists with the fascist regimes of the twentieth century.

\footnotetext{
45 Ibid., 26-27.

46 Lagarde, Deutsche Schriften, 98.
} 
The Southern drive toward palingenesis was, in many ways, a temporal revolution. It was the launch of a new era rooted in eternal ideas. Southerners rejected the North's teleological sense of time. Northerners saw time as progressive, they prophesied liberal democracy and expanded rights as the apex and only future for modernity. The creation of a new nation was an effort to freeze time because for the South modernity was a destructive process erasing their traditional culture and identity. The Southerner was not equal to women or blacks, the Southern man was superior. For the South, this was a timeless truth. Through breaking away from Northern liberalism, Southerners were attempting to re-anchor their identity in group supremacy. The South's palingenesis was an attempt to control the future and define it on its own terms. The perfection of slavery, evident in history and nature, was to be the foundation of this insulated and rebirthed society. The Southern intelligentsia sought to create a forward looking slave society which embraced aspects of modernity. The South wanted to control industrialization and modernity much like they controlled their slaves. They sought to harness modern technology to bolster their slave regimes. In their eyes, a modern slave society would be neither capitalist nor communist, but would be a 'third way,' or a radical alternative to both.

Part of why Southern intellectuals believed in the perfection of slavery was through its eternal and timeless presence in human history. The South regarded slavery as their own peculiar institution whose heritage reached back to the classical era. They believed that its ubiquitous presence in history proved its validity. The Southern intelligentsia believed their timeless institution was under assault by modern, false, and abstract ideologies that had recently come into fashion. ${ }^{47}$ To defend slavery against social change was to freeze time. It was to believe slavery to be a law of nature or God's creation. In the face of the abolitionist movement, Southerners increasingly gravitated to an illiberal palingenetic vision of the future. Perhaps the best example of the melding of illiberalism and palingenesis was through Alexander Stephen's infamous 'Cornerstone of the Confederacy' speech. As Vice President of the Confederate States of America, he reiterated the sense of Northern degeneracy in saying 'Those ideas [Equality and Natural Rights], however, were fundamentally wrong. They rested upon the assumption of the equality of races'. Stephens then outlines the Confederate States of America as a master race utopia. In doing so, he iterates the Southern promotion of a revolutionary new social order in exalting slavery as an axiom of nature: 
Our new Government is founded upon exactly the opposite ideas ... its cornerstone rests, upon the great truth that the negro is not equal to the white man; that slavery, subordination to the superior race, is his natural and normal condition. This, our new Government, is the first, in the history of the world, based upon this great physical, philosophical, and moral truth ... It is the first Government ever instituted upon strict conformity to nature, and the ordination of Providence ... ${ }^{48}$

That is, not based upon abstract and false ideologies which the Southern intelligentsia identified, but rather the eternal truths of God and nature. Under this perspective, social transformation and emancipation was unnatural.

The best defender of the mythic perfection of Southern slavery was Fitzhugh. In fact, he bolstered the notion of slavery's excellence in arguing that the institution defended his society from Northern 'isms' of change: 'Society has been so quiet and contented in the South ... that its attention has not been awakened to the revolutionary tumults, uproar, mendicity and crime of free society. ${ }^{\prime 9} \mathrm{He}$ contrasts the chaos of the North to the stability of the South: 'such defects do not exist in slave society, that we are not troubled with strikes, trade unions, phalasteries [sic], communistic establishments... and the thousand other isms that deface and deform free society. ${ }^{50}$ For the Southerners who read the works of these intellectuals, the message was clear: a new nation would be able to freeze the perfection of the South and insulate it from liberal progressive time.

Part of the South's vision for a new modernity consisted of a middle ground, or Third Way, in which the new South would be neither capitalist nor socialistbut the perfection of both. A common thread between fascist movements was an attempt to find a middle ground between communism and capitalism. Fitzhugh advocated Southern Paternalism as an institution which exceeds the goals, social welfare, and compassion of socialism and communism. In his own words, 'A Southern farm is the beau ideal of Communism. ${ }^{51}$ He goes on to state: 'The master increases the provision for the family as the family increases in number and helplessness. It is a beautiful example of communism, where each one receives not according to his labor, but according to his wants. ${ }^{.52}$

\footnotetext{
48 Alexander Stephens, 'Cornerstone of the Confederacy', in The Causes of the Civil War, ed. Kenneth Stamp, 3rd revised edition (New York: Simon \& Schuster, 1991), 152-153.

49 Fitzhugh, Sociology of the South, iii.

$50 \quad$ Ibid., 59 .

51 Ibid., 245 .

$5^{2}$ Ibid., 29.
} 
Hammond and Fitzhugh both believed that slavery perfected Southern society and only Southern society could properly respond to modernity. An orderly South was needed to roll back the 'conflagration' of the Enlightenment and the liberal values of equality and democracy unleashed through the American and French Revolutions. Southerners believed it was imperative to industrialize the South in order to continue to be a prosperous, commercial, and viable nation. It was essential not simply to create a new nation but to create a modern nation to ensure the South's proper place in the world. James Dunwoody Brownson De Bow created De Bow's Review, in which Fitzhugh and a whole host of Southern intellectuals published works to advance the modernization of the South's slave regime. ${ }^{53}$ One such article in De Bow's Review stated: 'She [The South] must resort to the same means by which power has been accumulated in the North .... it will place us in a condition to dictate our own terms .... [and] will prove our surest defense either against foreign aggression or domestic revolt. ${ }^{24}$ In fact, this drive toward modernization is why Hughes believes society's needs take priority over individual rights. In Treatise, he states: 'Existence and Progress are ultimate rights. They are the final and supreme objects of social organization. They are its end and aim. All other rights are incidental. ${ }^{55}$ This was the South's illiberal vision of progress.

It was in Fitzhugh's promotion of a temporal revolution in which he re-articulated notions of illiberal conformity, indoctrination, and the denial of individual rights. Part of his worldview was that the individual was always subordinated to society, something he made clear through his constant analogies between humans, bees, and ants: 'The social body is of itself a thinking, acting, sentient being. This is eminently observable with the lower animals. Bees and herds perform their evolutions with too much rapidity and precision, to leave any doubt but that one mind and one feeling, either from within or without, directs their movements.' Fitzhugh used the analogy of the hive to criticize classic liberals ideals such as the freedom of speech: 'The great error of modern philosophy is the ignorance or forgetfulness of this fact. The first departure from it was not the Reformation ... but the doctrine of the right of private judgment... Human equality, the social contract, the let-alone and selfish doctrines of political economy, universal liberty, freedom of speech, of the press,

53 Sublette, 577.

54 'Department of Manufacture and Mines: Extension of Cotton and Wool Factories in the South,' De Bow's Review: Agricultural, Commercial, Industrial Progress and Resources 11, issue 3 (1851): 19. Available at Making of America, accessed November 27, 2019, http://quod .lib.umich.edu/m/moajrnl/acg1336.1-11.003/331. 
and of religion, spring directly from this doctrine'. ${ }^{56}$ In this way, Fitzhugh like his fascist predecessors in the next century articulated a unified society sharing a common sense of past, present, and future. Part of his vision of a new Southern modernity was the creation of uniquely Southern institutions spreading Southern pro-slavery ideology as a means to defend against Northern degeneracy. In Cannibals All!, he wrote: 'political economy, and all other systems of moral science, which we derive from Europe, are tainted with abolition, and at war with our institutions. We must build up centres of trade, of thought and fashion at home. We must become national, nay, provincial, cease to be imitative cosmopolitans. We must especially, have good colleges and universities, where young men may learn to admire their homes, not to despise them. ${ }^{57}$ Fitzhugh advocated a renewed South that rejected liberalism and fostered ideological conformity. Objectives that could only be achieved in a palingenesis.

Southern and Völkisch thinkers shared similar mythical conceptions of the perfect harmony and stability of their societies. Like the slave societies of the South, Riehl argued that the true Volk was stable and knew nothing of the wants of communism. The Volk was insulated from the isms of modernity. In fact, Riehl, much like Fitzhugh, compared the Volk to one giant family, holding all property in common, and considered it to be an 'ancestral Communism. ${ }^{58}$ Both Riehl and Fitzhugh believed that modernity destroyed the perfect communism which had already existed in their mythical conceptions of society. It was this rose-tinted perspective of the past that proto-fascists advocated for the foundation of a new order. Part of the temporal revolutionary aspect of the proto-fascists was not simply an effort to freeze time, but the advocation of a new nation, a new culture, and a new man. It was through this break with the present that the forces of degeneracy would finally be broken. Völkisch intellectuals believed that a German Revolution was necessary to purify the nation and give their communities the necessary space to rise to their true nature. ${ }^{59}$ Likewise, the bid to establish a Southern Confederacy was an effort of revolutionary palingenesis. This was a slavocratic revolution meant to bring forth the traditions of the South to combat the degeneracy and modernity from the North. This idea was taken to its logical extreme and manifested itself in the formation of the Confederate States of America. This new state was meant to preserve the inequality between men, invoke order in society, and

\footnotetext{
56 Fitzhugh, Cannibals All!, 197.

57 Ibid., 88-89.

58 Riehl, Land und Leute, 104, 164.

59 Lagarde, Deutsche Schriften, 209.
} 
cultivate an elevated aristocracy. Palingenesis combined with a social, politi$\mathrm{cal}$, and temporal revolution links the ideology of Southern and Völkisch intellectuals to fascism. For instance, Fitzhugh's thesis of the failure of free society involved a marriage of Southern paternalism and socialism in much the same way Völkisch ideology would lead to the merging of German nationalism and socialism in the rise of Nazism. ${ }^{60}$

\section{7}

\section{Conclusion and Discussion: Toward a Fascist Revolution?}

The Southern intellectuals sought the creation of a new man and a new modernity in a new nation. This palingenesis would enable Southerners to end their status as victims under Northern degeneracy. It would preserve traditional social roles between men, women, and race. It would be a forward looking ideology, a distinctly Southern modernity as an alternative to the liberal society of the North. The core of the Southern palingenesis was the creation of a new type of industrial slave society. Although the South prized slavery as the ideal of communist goals, they abhorred the ideology. The Southern intelligentsia sought a third way between capitalism and communism because they believed free labor begat revolution and degeneracy. Low paid workers fermented revolution, abolition and feminism. Above all, a working class led to socialism, not only in terms of the emancipation of their slaves as property but in inaugurating equality between race and sex. To fight against degeneracy was to fight against democratic participation, abolitionism, feminism, socialism, and communism. To control and roll back the discontent of the working class and the revolutions they ignited, it was necessary to control them as tightly as possible, hence, a renewed and modernized slave state was the answer.

Cumulatively, the proslavery ideology of the South was proto-fascist. The palingenesis of the South did not completely resemble the fascist regimes of the next century. As previously stated, the South's proto-fascism shares the same ineliminable core of the rejection of modernity and proposal for a radical new order as interwar fascist regimes such as Nazi Germany or Mussolini's Italy. Historian George L. Mosse, said: 'Ideas of regeneration, of sacrifice, and a vision of utopia were the staple of all fascism. ${ }^{61}$ Indeed, Southern calls for a new nation centered on their notions of race and sex heralded the Nazi's

\footnotetext{
6o Harvey Wish, George Fitzhugh: Propagandist of the Old South (Baton Rouge: Louisiana State University Press, 1943), 174.

61 Mosse, The Fascist Revolution, xv.
} 
doctrine of master race utopianism and Lebensraum when a South Carolinian politician polemicized:

Unite, and your slave property shall be protected ... Unite, and ... . California shall be a slave State; the dismembered territory of Texas shall be restored, and you shall enjoy a full participation in all the territory which was conquered by your blood and treasure. Unite, and you shall form one of the most splendid empires on which the sun ever shone, of the most homogeneous population, all of the same blood and lineage. ${ }^{62}$

The Southern nationalists fought and died for their palingenesis. The War for Southern Independence ended with Northern victory.

Nonetheless, these ideas continued to live on in a defeated South. For the Völkisch proto-fascists, their ideas would find new life and be incorporated into Nazi Germany. One question than can be conjectured is - if the proto-fascism was similar between the Antebellum South and the Völkisch movement - how did the experience of war lead to completely divergent directions? In post-First World War Germany, liberal modernity was associated with defeat coupled with a weak Weimar Republic. In the United States, liberalism triumphed so soundly that the South's resentment of defeat never aroused the mass mobilization on the scale of the Europeans. After all, the North forced liberal-democratic institutions on the vanquished South. In Europe, proto-fascism was able to take root because liberal-democracy's validity was questioned with the defeated nations and their ruined economies. For a defeated South, the best they could do was Klan terrorism and Jim Crow. The triumph of liberalism ensured that Jim Crow would never reach the extent of the Holocaust. Under Northern occupation, racist terrorists had to be secretive about their activities.

This article pushed the timeline back for the literature comparing the United States with fascist regimes to before the Civil War. In so doing, these conclusions contextualize the many similarities in American history which other scholars have pointed out. Robert E. Bonner, Robert O. Paxton, Jason Stanley, and Joseph L. Yannielli researched the emergence of proto-fascist movements in the United States after the Civil War, anticipating the rise of racist-fascism in Nazi Germany. Although never being able to manifest itself as a regime, many

62 Langdon Cheves, Speech of the Honorable Langdon Cheves, in the Southern Convention, at Nashville, Tennessee, November 14, 1850 (Nashville: Southern Rights Association, 1850), 30. Available at Hathitrust.org, accessed November 27, 2019, https://hdl.handle.net/2027/inu .32000009084676 ? urlappend $=\%{ }_{3}$ Bseq $=34$. 
fascist features survived and evolved after the Civil War such as in the American eugenics movement's influence on Nazi Germany and the connection between the contemporary ultranationalism of the American and European far right. ${ }^{63}$ Furthermore, the notion of proto-fascism, like post-fascism, deepens our understanding of the 'protean' or adaptive qualities of fascism to historical and external forces. The ineliminable core of palingenesis explains similarities to contemporary 'pseudo-fascism' - such as through American President Donald Trump's 'Make American Great Again' slogan for instance. This study has shown that there was a continuum of illiberal forces which preceded and survived through the Southern nationalist movement that culminated in the American Civil War. The proto-fascist features of the Antebellum South explain many of the similarities other historians have drawn between the Third Reich and the post-Civil War South. As such, the Antebellum South of the United States warrants serious study in the discourse of comparative fascism.

63 Edwin Black, War Against the Weak: Eugenics and America's Campaign to Create a Master Race (Washington, D.C.: Dialog Press, 2012); James Q. Whitman, Hitler's American Model: The United States and the Making of Nazi Race Law (Princeton: Princeton University Press, 2018). 